\title{
PENGARUH EPS, PER, ROE, DAN DER TERHADAP RETURN SAHAM PADA PERUSAHAAN FARMASI YANG TERDAFTAR DI BURSA EFEK INDONESIA PERIODE 2011-2014
}

\author{
Arisa Nurlitasari \\ arisa.nurlitasari@gmail.com
}

\begin{abstract}
ABSTRACK
This study entitled Effect of EPS, PER, ROE, and DEROn Stock Return in The Companies Pharmacy Sector Listed in Indonesian Stock Exchange. The purpose of this study to determine the effect of EPS, PER, ROE, and DERsimultaneously and partiallyto stock return consumer sector manufacturing companies in Indonesian Stock Exchange. The population of this research is all consumption sectors of manufacturing companies listed on the Indonesia Stock Exchange during the period 2011-2014. Based on these criteria the final sample obtained samples of 9 companies. Financial statement data used are the ones with the accounting year ended December 31, 2011-2014. While the return of data used is the stock return 31 December 2011-31 December 2014. Therefore, the data used in the research are secondary data, to determine the accuracy of the model needs to be tested on some of the assumptions underlying the classical regression model. Deviationclassical assumptions used in this study include Normality Test, Test of Autocorrelation,Multikolonieritas Test, andTest heteroscedasticity. The results of the analysis of the data showed a positive effect of EPS and PER significant impact on stock returns. The results of the analysis of the data shows the influence of ROE and DER is positif and not significant to the stock return.
\end{abstract}

Keywords: EPS, PER, ROE, DER, dan Stock Return

\section{PENDAHULUAN}

Menghadapi era globalisasi dan perdagangan bebas, persaingan usaha disadari semakin ketat, maka setiap perusahaan dituntut untuk lebih mengoptimalkan kinerja perusahaannya agar dapat mempertahankan dan mengembangkan usahanya serta mencapai tujuan perusahaan. Industri farmasi merupakan industri yang berbasis riset. Salah satu hal yang tidak bisa dihindarkan adalah timbulnya persaingan tajam antar perusahaan farmasi. Oleh karena perusahaan farmasi di Indonesia dituntut untuk mampu bersaing dengan cara membuat inovasi, promosi dan sistem pemasaran yang baik, serta kualitas produk yang optimal.

Tujuan perusahaan yang ingin dicapai secara umum adalah untuk menambah keuntungan (profit) dan memaksimalkan kekayaan (wealth) dalam arti memaksimalkan nilai perusahaan bagi pemegam saham. Nilai perusahaan yang 


\section{JURNAL MANAJEMEN VOL. 5 NO. 2 DESEMBER 2015}

dimaksud adalah merupakan nilai sekarang perusahaaan terhadap prospek masa depan mengembangkan investasi itu sendiri. Pengembangan satu investasi dapat dilakukan melalui wadah atau lembaga yang disebut pasar modal. Perkembangan pasar modal di Indonesia yang pesat merupakan indikator bahwa pasar modal merupakan alternatif sumber dana disamping perbankan, selain itu dengan semakin berkembangnya pasar modal juga menujukkan bahwa kepercayaan pemodal akan investasi di pasar modal Indonesia cukup baik.

Bagi para investor yang akan melakukan pembelian saham suatu perusahaan penilaian terhadap kemampuan perusahaan dalam mendapatkan dan mengelola modal merupakan hal yang penting. Apabila suatu perusahaan dapat memanfaatkan modalnya dengan baik dalam menjalankan usaha maka semakin besar kemampuan perusahaan tersebut untuk bertumbuh sehingga harga saham perusahaan tersebut diperkirakan akan meningkat dan pada akhirnya semakin meningkat pula return yang diperoleh. Apabila suatu perusahaan tidak dapat memanfaatkan modalnya dengan baik dalam menjalankan usaha maka semakin kecil kemungkinan perusahaan tersebut untuk bertumbuh sehingga harga saham perusahaaan tersebut diperkirakan akan menurun dan pada akhirnya return yang diperoleh juga semakin menurun.

Salah satu cara yang biasa digunakan dalam menilai perusahaan adalah pendekatan fundamental. Pendekatan tersebut terutama ditujukan kepada faktor-faktor yang pada umumnya berada di luar pasar modal, yang dapat mempengaruhi harga saham di masa-masa mendatang. Hal-hal yang termasuk dalam analisis fundamental antara lain adalah analisis ekonomi dan industri, penilaian perusahaan secara individu baik dengan menggunakan variabel penelitian seperti dividen maupun pendapatan (income).

Dalam analisis fundamental terdapat beberapa rasio keuangan yang dapat mencerminkan kondisi keuangan dan kinerja suatu perusahaan. Rasio yang digunakan dalam penelitian ini meliputi Earning Per Share (EPS), Price Earning Ratio (PER), Return On Equity (ROE), dan Debt To Equity Ratio (DER). Earning Per Share (EPS) atau laba per lembar saham merupakan salah satu rasio profitabilitas yang digunakan sebagai alat analisis untuk mengetahui tingkat profitabilitas sebuah perusahaan. Earning Per Share (EPS) diperoleh dari laba yang tersedia bagi pemegang saham dibagi dengan jumlah rata-rata saham yang beredar. Price Earning Ratio (PER) merupakan suatu rasio yang 
menggambarkan bagaimana keuntungan perusahaan atau emiten saham terhadap harga shamnya. Price Earning Ratio (PER) digunakan untuk mengukur nilai perusahaan pada saat tertentu berdasarkan laba yang dicapainya yang dihitung dengan membagi saham dengan labanya.

Return On Equity (ROE) merupakan salah satu rasio profitabilitas yang dapat digunakan untuk mengukur seberapa efektif ekuitas yang diberikan oleh para pemodal dan dikelola oleh pihak manajemen untuk beroperasi menghasilkan keuntungan. Semakin tinggi nilai ROE menunjukan semakin efisien perusahaan menggunkan modal sendiri untuk menghasilkan laba. Dengan meningkatnya laba perusahaan, maka harga saham pun akan meningkat dan dengan begitu return yang didapat juga semakin besar.

\section{KAJIAN PUSTAKA DAN HIPOTESIS}

\section{Pasar Modal}

Pasar modal merupakan salah satu alternatif investasi bagi masyarakat. Melalui pasar modal, investor dapat melakukan investasi di beberapa perusahaan melalui pembelian surat-surat berharga yang ditawarkan atau yang diperdagangkan di pasar modal. Sementara itu, perusahaan atau sring disebut dengan emiten dapat memperoleh dana yang
Rasio lain yang diperkirakan dapat mempengaruhi return saham adalah Debt To Equity Ratio (DER). Debt To Equity Ratio (DER) merupakan rasio solvabilitas yang mencerminkan kemampuan perusahaan dalam memenuhi seluruh kewajibannya yang ditunjukkan oleh beberapa bagian modal sendiri yang digunakan untuk membayar hutang. Semakin tinggi DER menunjukkan semakin besar total hutang terhadap total ekuitas (Ang, 1997), juga akan menunjukkan semakin besar ketergantungan perusahaan terhadap pihak luar (kreditur) sehingga tingkat risiko perusahaan semakin besar. Hal ini akan berdampak pada menurunnya harga saham di bursa, sehingga return saham akan menurun.

dibutuhkan dengan menawarkan suratsurat berharga tersebut. Adanya pasar modal memungkinkan para investor untuk memiliki perusahaan yang sehat dan berprospek baik (Hermuningsih, 2012).

\section{Return Saham}

Return merupakan hasil yang diperoleh dari kegiatan investasi. Return dibedakan menjadi dua, yaitu return realisasi (return yang terjadi atau dapat juga disebut return sesungguhnya) dan return ekspektasi 


\section{JURNAL MANAJEMEN VOL. 5 NO. 2 DESEMBER 2015}

(return yang diharapkan oleh investor). Return saham adalah tingkat keuntungan yang dinikmati oleh pemodal atas suatu investasi yang dilakukannya (Ang, 1997). Setiap investasi baik jangka panjang maupun jangka pendek mempunyai tujuan utama untuk mendapatkan keuntungan yang disebut return, baik langsung maupun tidak langsung (Ang, 1997). Investasi secara sederhana dapat diartikan sebagai suatu kegiatan menempatkan dana pada satu atau lebih asset selama periode tertentu dengan harapan dapat memperoleh penghasilan atau peningkatan nilai investasi. Konsep risiko tidak terlepas kaitannya dengan return, karena investor selalu mengharapkan tingkat return yang sesuai atas setiap risiko investasi yang dihadapinya.

\section{Analisis Fundamental}

Analisis fundamental adalah usaha untuk menganalisis berbagai faktor yang berhubungan dengan saham yang akan dipilih melalui analisis perusahaan, analisis industri, analisis ekonomi makro serta metode-metode analisis lain untuk mendukung analisis saham yang akan dipilih (Hermuningsih, 2012). Banyak faktor yang mempengaruhi penjualan dan biaya-biaya, seperti faktor yang bisa dikendalikan perusahaan (misal: pemilihan jenis mesin, pemilihan jenis teknologi, pemilihan karyawan, dan lain-lain) dan faktor yang tidak bisa dikendalikan perusahaan (misal: suku bunga, pertumbuhan ekonomi, dan lain-lain). Salah satu aspek penting dari analisis fundamental adalah analisis laporan keuangan, karena dengan menggunakan hal tersebut dapat diperkirakan keadaan, atau posisi dan arah perusahaan (Hermuningsih, 2012).

Rasio keuangan adalah angka yang diperoleh dari hasil perbandingan dari suatu pos laporan keuangan dengan pos lainnya yang mempunyai hubungan yang relevan dan signifikan (berarti). Rasio keuangan hanya menyederhanakan informasi yang menggambarkan hubungan antara pos tertentu dengan pos lainnya, dengan kata penyederhanaan ini dapat menilai secara cepat hubungan antara pos tadi dan dapat membandingkannya dengan rasio lain sehingga kita dapat memperoleh informasi dan memberikan penilaian (Harahap, 2004). Menurut Nianggolan (2004) ada beberapa rasio keuangan yang digunakan untuk mengukur kinerja keuangan perusahaan yaitu:

a. Earning Per Share (EPS)

\section{Earning Per Share (EPS)} digunakan untuk mengukur keberhasilan manajemen dalam mencapai keuntungan bagi para pemilik perusahaan. Menurut Darmadji dan Fakhruddin (2008), Earning Per Share (EPS) menggambarkan 
profitabilitas perusahaan yang tergambar dalam setiap lembar saham. Semakin tinggi nilai Earning per Share (EPS) maka semakin besar laba dan kemungkinan peningkatan jumlah dividen yang diterima pemegang saham. Semakin tinggi Earning Per Share (EPS) maka semakin mahal harga suatu saham. Sebaliknya, apabila semakin rendah Earning Per Share (EPS) maka murah harga suatu saham. Earning Per Share (EPS) dapat dirumuskan sebagai berikut:

$$
\begin{aligned}
& \text { EPS } \\
& =\frac{\text { Laba Bersih Setelah Pajak }}{\text { Jumlah Saham Beredar }}
\end{aligned}
$$

b. Price Earning Ratio (PER)

Menurut Robbert Ang (1997), Price Earning Ratio (PER) merupakan perbandingan antara harga pasar suatu saham (market price) dengan Earning Per Share (EPS) dari saham yang bersangkutan. Kegunaan Price Earning Ratio (PER) ini adalah untuk melihat bagaimana pasar menghargai kinerja saham suatu perusahaan terhadap kinerja perusahaan yang dicerminkan oleh EPS nya. Semakin besar Price Earning Ratio (PER) suatu saham maka saham tersebut semakin mahal terhadap pendepatan bersih per sahamnya. Sedangkan saham yang memiliki Price Earning Rtaio (PER) semakin kecil akan semakin bagus, karena saham tersebut semakin murah. Price
Earning Ratio (EPS) dapat dirumuskan sebagai berikut:

$$
P E R=\frac{\text { Harga Per Saham }}{\text { Laba Bersih Per Saham (EPS) }}
$$

c. Return On Equity (ROE)

$$
\text { Return On Equity }
$$

(ROE) merupakan salah satu rasio profitabilitas yang banyak digunakan untuk kinerja keuangan perushaan. Return On Equity (ROE) bertujuan untuk mengukur kemampuan perusahaan dalam menghasilkan laba atas modalnya sendiri. Menurut Sartono (2001), Return On Equity (ROE) sering disebut juga dengan rate of on Net Worth yang merupakan kemampuan perusahaan dalam menghasilkan keuntungan dengan ekuitas yang dimiliki. Semakin besar presentase Return On Equity (ROE) yang dimiliki oleh perusahaan maka semakin besar dan efektif kinerja perusahaan dalam menghasilkan laba. Menurut Darmadji dan Fakhruddin (2006), Return On Equity (ROE) dapat dirumuskan sebagai berikut:

$$
\begin{aligned}
& \text { ROE } \\
& =\frac{\text { Laba Bersih Setelah Pajak }}{\text { Modal Sendiri }}
\end{aligned}
$$

d. Debt To Equity Ratio (DER)

$$
\text { Menurut Darsono (2005), Debt To }
$$

Equity Ratio (DER) menunjukkan presentase penyediaan dana oleh pemegang saham kepada pembeli 


\section{JURNAL MANAJEMEN VOL. 5 NO. 2 DESEMBER 2015}

pinjaman. Semakin tinggi rasio, semakin rendah pendanaan perusahaan yang disediakan oleh pemegang saham. Debt To Equity Ratio (DER) menggambarkan kemampuan perusahaan dalam memenuhi kewajibannya yang ditunjukkan oleh beberapa bagian dari modal sendiri atau ekuitas yang digunakan untuk membayar hutang. Rumus yang digunakan untuk menghitung Debt To Equity Ratio adalah sebagai berikut:

$$
D E R=\frac{\text { Total Hutang (Debt) }}{\text { Ekuitas (Equity) }}
$$

\section{METODOLOGI}

Sifat penelitian ini adalah deskriptif kuantitatif dengan populasi penelitian adalah perusahaan sektor industri farmasi selama periode 2011-2014, yaitu sepuluh perusahaan yang go public yang bergerak di sektor industri farmasi. Dalam

\section{HASIL DAN PEMBAHASAN}

Berdasarkan analisis yang telah dilakukan secara parsial bahwa variabelvariabel yaitu EPS dan PER berpengaruh
H1 : Earning Per Share (EPS) berpengaruh positif terhadap return saham H2 : Price Earning Ratio (PER) berpengaruh positif terhadap return saham H3 : Return On Equity (ROE) berpengaruh positif terhadap return saham

H4 : Debt To Equity Ratio (DER) berpengaruh negatif terhadap return saham

H5 : Earning Per Share (EPS), Price Earning Ratio (PER), Return On Equity (ROE), Debt To Equity Ratio (DER) berpengaruh signifikan terhadap return saham.

penelitian ini variabel dependen yang digunakan adalah Return Saham. Variabel independen terdiri dari Earning Per Share (EPS), Price Earning Ratio (PER), Return On Equity (ROE), dan Debt To Equity Ratio (DER).

signifikan terhadap return saham dan ROE dan DER tidak berpengaruh signifikan. Hal ini dapat dilihat dari hasil uji regresi linier berganda : 
Hasil Uji Regresi Linier Berganda

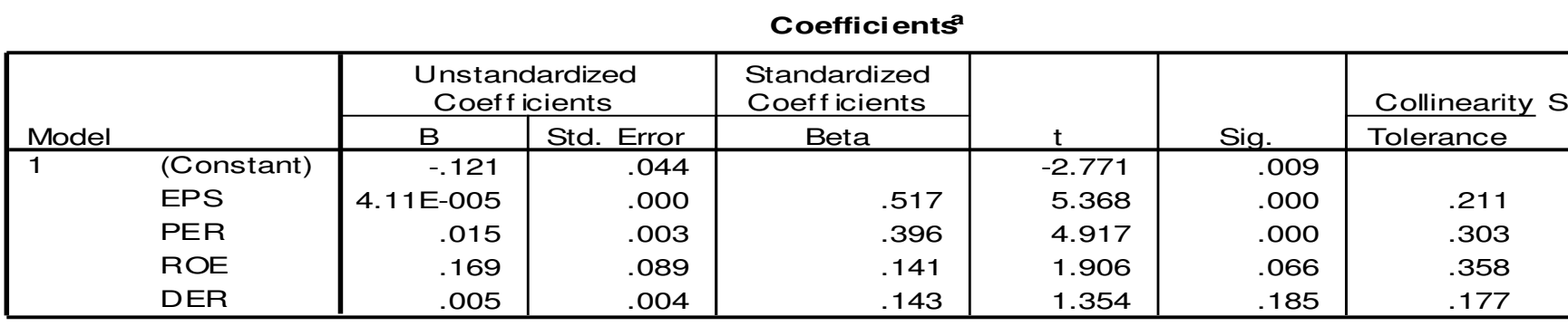

a. Dependent Variable: Return_saham

$$
\text { Return saham }=-0,121+4,11 \mathrm{E}-005+0,015+0,169+0,005
$$

Nilai konstanta persamaan tersebut adalah sebesar -0,121. Angka tersebut menunjukkan return saham yang diperoleh oleh perusahaan sebesar $-0,121$ bila variabel EPS $\left(\mathrm{X}_{1}\right), \operatorname{PER}\left(\mathrm{X}_{2}\right), \operatorname{ROE}\left(\mathrm{X}_{3}\right)$ dan DER $\left(\mathrm{X}_{4}\right)$ dianggap konstan. Variabel Earning Per Share (EPS) memiliki koefisien regresi yang positif yaitu sebesar (+) 4,11E-005. Nilai koefisien positif menunjukkan bahwa EPS terhadap return saham berpengaruh positif. Hal ini menggambarkan bahwa jika terjadi kenaikan EPS sebesar 1\%, maka return saham pada perusahaan akan naik sebesar 4,11E-005 dengan asumsi variabel independen lain dianggap konstan. Variabel Price Earning Ratio (PER) memiliki nilai koefisien yang positif yaitu sebesar (+) 0,015. Nilai koefisien positif menunjukkan bahwa PER terhadap return saham berpengaruh positif. Hal ini menggambarkan bahwa jika terjadi kenaikan PER sebesar 1\%, maka return saham akan menyebabkan kenaikan nilai return pada perusahaan sebesar 0,015 dengan asumsi variabel independen yang lain dianggap konstan. Variabel Return On Equity (ROE) memiliki nilai koefisien yang positif yaitu sebesar $(+) 0,169$. Nilai koefisien positif menunjukkan bahwa ROE terhadap return saham berpengaruh positif. Hal ini menggambarkan bahwa jika terjadi kenaikan ROE sebesar 1\%, maka return saham akan menyebabkan kenaikan nilai return pada perusahaan sebesar 0,169 dengan asumsi variabel independen yang lain dianggap konstan. Variabel Debt To Equity Ratio (DER) memiliki nilai koefisien yang positif yaitu sebesar $(+)$ 0,005. Nilai koefisien positif menunjukkan bahwa DER terhadap return saham berpengaruh positif. Hal ini menggambarkan bahwa jika terjadi kenaikan DER sebesar 1\%, maka return saham akan menyebabkan kenaikan nilai return pada perusahaan sebesar 0,005 dengan asumsi variabel independen yang lain dianggap konstan. 


\section{JURNAL MANAJEMEN VOL. 5 NO. 2 DESEMBER 2015}

Variabel EPS dan PER menunjukkan arah positif signifikan berpengaruh terhadap return saham, sedangkan variabel ROE dan DER menunjukkan arah positif tidak signifikan berpengaruh terhadap return saham karena tingkat signifikannya $>0,05$.

\section{KESIMPULAN}

Penelitian ini bertujuan untuk mengetahui pengaruh EPS, PER, ROE, dan DER terhadap Return saham pada perusahaan Farmasi yang terdaftar di BEI. Berdasarkan penelitian yang dilakukan pada perusahaan Farmasi maaka dapat diambil kesimpulan sebagai berikut : 1)

\section{DAFTAR PUSTAKA}

Ang, Robert. Buku Pintar Pasar Modal Indonesia (The Intelligent Guide to. Indonesian Capital Market). Jakarta: Mediasoft Indonesia. Brigham, E.F., dan J. Houtson., 2001. Manajemen Keuangan. Penerjemah Hermawan Wibowo. Edisi kedelapan. Edisi Indonesia. Buku II. Erlangga, Jakarta.

Bawono, Tri Handjono., 2013. "Pengaruh Kinerja Keuangan Perusahaan Terhadap Return Saham Dengan Investment Opportunity Set Sebagai Variabel Mediasi Pada Perusahaan Syariah yang terdaftar di BEI tahun 2007-2010”. Skripsi, FE Universitas Sarjanawiyata Tamansiswa, Yogyakarta.

Darnadji, Tjiptono dan Hendy M Fakhruddin, 2006. Pasar Modal di
Earning Per Share (EPS) berpengaruh signifikan terhadap return saham, 2) Price Earning Ratio (PER) berpengaruh signifikan terhadap return saham, 3) Return On Equity (ROE) tidak berpengaruh signifikan terhadap return saham, 4) Debt To Equity Ratio (DER) tidak berpengaruh signifikan terhadap return saham; 5) Earning Per Share (EPS), Price Earning Ratio (PER), Return On Equity (ROE) dan Debt To Equity Ratio (DER) secara bersama-sama berpengaruh signifikan terhadap return saham pada perusahaan Farmasi yang terdaftar di BEI.

Indonesia Pendekatan Tanpa Tanya Jawab, PT Salemba Empat, Jakarta.

Darsono dan Ashari., 2005. Pedoman Praktis Memahami Laporan Keuangan, Andi, Yogyakarta.

Ghozali, I., 2011. Aplikasi Analisis Multiviariate Dengan Program SPSS, Badan Penerbit Universitas Diponegoro, Semarang.

Harahap, Sofyan syafri,2002. Analisa Kritis Atas Laporan Keuangan, PT Raja Grafindo Persada, Jakarta.

Hermuningsih, Sri., 2012. Pengantar Pasar Modal Indonesia. Yogyakarta. UPP STIM YKPN. 
Jogiyanto Hartono., 2005.

Teori Portofolio dan Analisis Investasi. Yogyakarta: BPFE.

Marzuki Usman, 1989. Peranan Perbankan Pasar Modal sebagai Wahan Penyedia Dana Bagi Pembangunan. Jakarta 1989.
Nsinggolan, Pahala., 2004., Cara Mudah Memahami Akuntansi, PPM, Jakarta.

Santoso, Singgih., 2001. Buku Latihan Statistik Parametrik, PT Elek Medis Komputindo, Jakarta.

Sugiyono. 2010. Metode Penelitian Bisnis. Bandung : alfabeta. 